\title{
Reproductive performance of begayt sheep under different management systems in western zone of Tigray
}

\begin{abstract}
The study was conducted in North- Western zone of Tigray region, in Humera District Northern part of Ethiopia; with the objective of to measure reproductive performances of "Begayt" sheep under farmers and ranch management conditions. The data on reproductive performance of Begayt sheep $(n=150)$ kept at three different sheep farms in Western Zone of Tigray, Quafta Humera district, Government Ranch (GovR) $(n=50)$, Privet Ranch (PrivR) $(n=50)$ and Privet Farm (PrivF) $(n=50)$, under semi-intensive management system, were analyzed. General linear model was used for analyzing the data. The fixed effects in the model included location of flock, age, type of birth, sex of lamb and their interactions. The overall findings of reproductive traits such as fertility, prolificacy, single lambing, twinning rate, lambs born alive and sex ratio (male: female) were 92.67, 101.33, 89.86, 10.14, 96.33\% and 50.33:49.67, respectively. The highest value for twinning rate was recorded in GovR (13.04\%) and the lowest in $\operatorname{PrivF}(6.52 \%)$. All traits were significantly different $(\mathrm{P}<0.05)$ from each other except lambs born alive and season of birth were no significant $(\mathrm{P}>0.05)$ between flocks. The overall results revealed that age of dam, age at first service (AFS), service period (SP), age at first lambing (AFL) and lambing interval (LI) were $1078 \pm 2.2,579.61 \pm 0.6,206.25 \pm 0.2$, and $731.67 \pm 0.3$ and $256.60 \pm 0.3$ days, respectively. The results of ANOVA showed that locations had significant effect $(\mathrm{P}<0.05)$ on AFS and SP; however lambing interval and age at first lambing were not affected. Age of ewe, type of birth, sex of lamb(s) born and interaction between these factors did not influence the traits significantly. It was concluded that reproductive performance of Begayt sheep was modest so it is vital to improve management, nutritional and breeding practices at the farm.
\end{abstract}

Keywords: begayt sheep, farms, ranch, reproductive performance, traits
Volume 3 Issue 3 - 2016

\author{
Gebregiorgis Ashebir, Guesh Negash Haile, \\ Kidane Weldu \\ Mekelle University, Ethiopia
}

Correspondence: Gebregiorgis Ashebir, Mekelle University, College of Veterinary Medicine, 2084 Mekelle, Ethiopia, Email giorgisavet97@yahoo.com

Received: January 27, 2016 | Published: April 06, 2016

\section{Introduction}

Sheep production is one of the major parts of the livestock production system in the Northern part of Ethiopia. Small ruminants are widely reared in a crop-livestock farming systems and are distributed across different agro-ecological zones of Ethiopia. Sheep and goats production is an important activity for smallholders, particularly for resource poor farmers in many parts of the country. They provide their owners with a vast range of products and services such as immediate cash income, meat, milk, skin, manure, risk management and social functions. ${ }^{1}$ They are also sources of foreign currency. ${ }^{2}$ At the farm level, sheep contribute up to 63 percent of the net cash income derived from livestock production in the mixed farming system. ${ }^{3}$ Although diverse sheep and goats resources are found in Ethiopia, their productivity is low; the sector has not received a great deal of attention from scientists, administrators and legislators. ${ }^{4}$ According to the survey results of CSA (2014/2015) about 29.33million sheep are estimated to be found in the country, out of which about 72.77 percent are females, and about 27.23percent are males. With respect to breed, almost all of the sheep are indigenous (99.78) percent. Ethiopia is home for at least 9 breeds and 14 traditional sheep populations. ${ }^{5}$ The average holding of sheep per household in Ethiopia ranges between $3.7^{6}$ to $31.6 .^{7}$ The result of the CSA (2014/2015) survey also revealed that about 21.19percent and 15.71 percent of the total holdings were with one to four head of sheep and goats, respectively. ${ }^{8}$ Ethiopian indigenous sheep mainly the lowland types are not exhaustively described breeds sheep are the second most production animals in the country, according to $\mathrm{FAO},{ }^{9}$ the total annual meat production comes from cattle (63\%), sheep (25\%) and goats (12\%). At the national level, sheep and goat account for about $90 \%$ of the live animal $/$ meat and $92 \%$ of skin and hide export trade value. ${ }^{3}$ In the lowlands, sheep with other livestock are the mainstay of the pastoral livelihoods. Sheep and goat breeds reared in Ethiopia are almost exclusively indigenous breeds. Indigenous sheep and goats have a high adaptability to extreme climatic conditions. The Begayt sheep is a long thin tailed; large size; convex face profile; with long pendulous ear breed, well adapted to a wide range of harsh environmental conditions in the North-Western of Tigray regional state and South- Western part of Eriteria. The population of this breed is around 87,339 in the study area (CSA 2014/15). ${ }^{8}$ Begayt sheep, with white body and red brown or spotted body and legs, are large in size, and their adult male and female weights are 45-60 and 40-50kg, respectively. In sheep breeding, reproductive performance is the key factor in connection with profitability. Reproductive performance of the lowland breeds mainly Begayt sheep breed was not studied previously. Therefore, the current study was designed to determine the reproductive performance of this overlooked breed "Begayt" sheep found in the Nortn-Western zone of the region at different management systems with the objective of to measure reproductive performances of "Begayt" sheep under farmers and ranch management conditions and to identify factors influencing the performances of sheep in the area. 


\section{Materials and methods}

\section{Study area}

The study was conducted in North- Western zone of Tigray region, in Humera district Northern part of Ethiopia; Humera is the widest district of the region which is the most oil seed (Sesame) producing area in the region as well as in the Country. Agro-ecologies of the area are classified as arid to semi-arid dry seasons. The annual rainfall varies between 560 to $900 \mathrm{~mm}$ and in a bimodal pattern with small rains between March and April and main rains from July to September. The annual mean temperature varies from $29^{\circ} \mathrm{C}$ to $42^{\circ} \mathrm{C}$ with a mean of $32^{\circ} \mathrm{C}$.

The reproductive performance of Begayt sheep ( $\mathrm{n}=150)$ was studied from 2014 to 2015 at three different farms in the Northwestern zone of Tigray region, Government sheep Ranch, (GovR) 'Mayweyni'(n=50), Privet sheep Ranch (PrivR) 'Adigoshu' $(\mathrm{n}=50)$ and Private sheep farm (PrivF) 'Mayweyni' $(\mathrm{n}=50)$ ). Performance traits like fertility, prolificacy, twinning rate, sex ratio, age at first service (AFS), service period (SP), age at first lambing (AFL) and lambing interval (LI) were recorded (annex 1). Fixed effect model was used to analyze the data. The fixed effects of flock, age, type of lambing (single or twin), sex of lamb born was included in the model.

The following model was used for analysis:

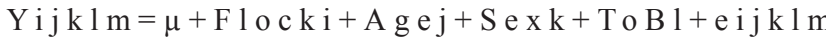
Where Yijklm=ith observation of traits, $\mu=$ Population mean, Flocki=ith flock, Agej=Age of ewe, Sexk=Sex of lamb(s) born (1=male, $2=$ female), ToBl=Type of birth (single or twin), Eijklm=Random error associated with each observation. Analysis of variance was performed to test the significance and qualitative data were analyzed using Chi square test.

\section{Results}

Overall average reproductive performance of Begayt sheep in three different farming systems are summarized in Table 1. Reproductive performance, such as fertility, prolificacy, single lambing, twinning rate, lambs born alive and sex ratio (male: female) were 92.67, $101.33,89.86,10.14,96.33 \%$ and $50.33: 49.67$, respectively. Of the total births, $50.33 \%$ and $49.67 \%$ cases of male and female and $89.86 \%$ and $10.14 \%$ single and twins births are recorded respectively. Twinning rate was the highest at GovR flock(13.04\%) and the lowest in PrivF flock $(6.52 \%)$. Flock significantly affected $(\mathrm{P}<0.05)$ all traits except number of lambs born alive. Season of birth had no significant $(\mathrm{P}>0.05)$ effect on these traits (Table 1). The overall means for age of dam, age at first service (AFS), service period (SP), age at first lambing (AFL) and lambing interval (LI) were $1078 \pm 2.2,579.61 \pm 0.6$, $206.25 \pm 0.2,731.67 \pm 0.3$ and $256.60 \pm 0.3$ days, respectively (Table 2), Flock differences for AD, AFS, SP and AFL were significant $(\mathrm{P}<0.05)$, however, LI was not significantly affected by it $(\mathrm{P}>0.05)$. Locations of flocks affected AFS and SP significantly $(\mathrm{P}<0.05)$; however lambing interval and age at first lambing were not affected $(\mathrm{P}>0.05)$. The age of ewe, type of birth, sex of lamb(s) born and interaction between these factors did not influence any of the traits significantly $(\mathrm{P}>0.05)$ (Table 3 ). Although the reports found are in months variation are take place in the different reproductive traits. Age at first lambing of 12.97 for sheep is reported in western Ethiopia ${ }^{10}$ which is lower (by half) than the current findings. Samuel $\mathrm{M}^{11}$ reported age at first lambing of 17.01 which is again lower than this finding. Tolera ${ }^{12}$ reported 21 months and under agro-pastoral traditionally managed sheep which is nearly in agreement with the current study. Most of the traits found in this study are in agreement with the findings found in Baluchistan, balochi sheep breeds by Jahan M et al. ${ }^{13}$

Table I Reproductive performance of Begayt sheep(\%)

\begin{tabular}{llllllllll}
\hline Location & $\mathbf{F}^{1}$ & $\mathbf{P}^{2}$ & LBA $^{3}$ & SoB $^{4}$ & & ToB $^{5}$ & \multicolumn{3}{c}{ SR $^{6}$} \\
\hline GovR9 & 92 & 104 & 97 & 87 & 14 & 86.96 & 13.04 & 49 & 51 \\
PrivRI0 & 94 & 108 & 96 & 86 & 13 & 89.13 & 10.87 & 46 & 54 \\
PrivFII & 92 & 98 & 96 & 87 & 14 & 93.48 & 6.52 & 56 & 44 \\
Mean & 92.67 & 101.33 & 96.33 & 86.66 & 13.33 & 89.86 & 10.14 & 50.33 & 49.67
\end{tabular}

$\mathrm{F}^{1}=$ fertility, $\mathrm{P}^{2}=$ prolificacy, $\mathrm{LBA}^{3}=$ lambs born alive, $\mathrm{SoB}^{4}=$ season of birth, $\mathrm{ToB}^{5}=$ type of birth, $\mathrm{SR}^{6}=\mathrm{Sex}$ ratio, $\mathrm{S}^{7}=$ spring lambing, $\mathrm{A}^{8}=$ autumn lambing, GovR $^{9}=$ Government Ranch, PrivR ${ }^{10}=$ Privet Ranch, PrivF ${ }^{11}=$ Privet Farm

Table 2 Reproductive performance (Mean \pm SE) of Begait sheep kept at three locations in the study area(days)

\begin{tabular}{lllllllll}
\hline Location & $\mathbf{N}$ & $\mathbf{A D}^{1}$ & $\mathbf{A F S}^{\mathbf{2}}$ & WAFS & $\mathbf{S P}^{3}$ & $\mathbf{A F L}^{4}$ & WAFL & LI $^{5}$ \\
\hline GovR6 & 50 & $1024 \pm 2.3^{\mathrm{b}}$ & $576 \pm 1 . \mathrm{I}^{\mathrm{a}}$ & $25.5 \pm 0.77^{\mathrm{a}}$ & $206.48 \pm 0.4^{\mathrm{b}}$ & $733 \pm 0.5^{\mathrm{b}}$ & $30.0 \pm 0.45$ & $254.32 \pm 0.5^{\mathrm{a}}$ \\
PrivR7 & 50 & $1118 \pm 2.4^{\mathrm{c}}$ & $582 \pm 0.9^{\mathrm{b}}$ & $24.6 \pm 0.80^{\mathrm{a}}$ & $207.10 \pm 0.3^{\mathrm{b}}$ & $730 \pm 0.2^{\mathrm{a}}$ & $28.9 \pm 0.62$ & $259.80 \pm 0.6^{\mathrm{a}}$ \\
PrivF8 & 50 & $1089 \pm 1.9^{\mathrm{a}}$ & $580 \pm 0.8^{\mathrm{b}}$ & $26.2 \pm 0.52^{\mathrm{b}}$ & $205.16 \pm 0.3^{\mathrm{a}}$ & $732 \pm 0.3^{\mathrm{b}}$ & $31.2 \pm 0.36$ & $257.82 \pm 0.6^{\mathrm{a}}$ \\
Mean & 150 & $1078 \pm 2.2$ & $579.61 \pm 0.6$ & $25.4 \pm 0.67$ & $206.25 \pm 0.2$ & $731.67 \pm 0.3$ & $30.0 \pm 0.51$ & $256.60 \pm 0.3$
\end{tabular}

$\mathrm{AD}^{\prime}=\mathrm{Age}$ of dam, $\mathrm{AFS}^{2}=\mathrm{Age}$ at first service, $\mathrm{SP}^{3}=$ Service period, $\mathrm{AFL}^{4}=\mathrm{Age}$ at first lambing, $\mathrm{L}^{5}=$ =lambing Interval, WAFS=Weight at first service, WAFL=weight at first lambing, GovR ${ }^{6}=$ Government Ranch, PrivR ${ }^{7}=$ Privet Ranch, PrivF $^{8}=$ Privet Farm. Means values with different superscripts within column differ significantly $(\mathrm{P}<0.05)$ 
Table 3 Analysis of variance for age at first service, service period, lambing interval and Age at first lambing

\begin{tabular}{|c|c|c|c|c|c|}
\hline \multirow{2}{*}{\multicolumn{2}{|c|}{$\begin{array}{l}\text { Sum of squares df } \\
\text { Age at first service }\left(R^{2}=44.9\right)\end{array}$}} & \multirow[t]{2}{*}{ Mean squares } & \multirow[t]{2}{*}{$\mathbf{F}$} & \multicolumn{2}{|c|}{ Significance } \\
\hline & & & & & \\
\hline Location & 542.916 & 2 & 271.458 & 6.558 & 0.002 \\
\hline AGE & 1200.642 & 20 & 60.032 & 1.45 & 0.118 \\
\hline TOB & 23.769 & I & 23.769 & 0.574 & 0.45 \\
\hline SEX & 190.704 & 4 & 47.676 & 1.152 & 0.337 \\
\hline AGE* SEX & 805.772 & 15 & 53.718 & 1.298 & 0.218 \\
\hline AGE*TOB & 14.136 & 1 & 14.136 & 0.342 & 0.56 \\
\hline Error & 4097.831 & 99 & 41.392 & & \\
\hline \multicolumn{6}{|c|}{ Service period $\left(R^{2}=37.6\right)$} \\
\hline Location & 51.361 & 2 & 25.681 & 3.82 & 0.025 \\
\hline AGE & 167.462 & 20 & 8.373 & 1.245 & 0.235 \\
\hline TOB & 0.0588 & I & 0.059 & 0.009 & 0.926 \\
\hline SEX & 12.193 & 4 & 3.048 & 0.453 & 0.77 \\
\hline AGE* SEX & 74.798 & 15 & 4.987 & 0.742 & 0.737 \\
\hline AGE*TOB & 0.763 & 1 & 0.763 & 0.113 & 0.737 \\
\hline Error & 665.563 & 99 & 6.723 & & \\
\hline \multicolumn{6}{|c|}{ Lambing interval $\left(R^{2}=\mathbf{2 8 . 0}\right)$} \\
\hline Location & 30.417 & 2 & 15.208 & 0.877 & 0.419 \\
\hline AGE & 296.552 & 20 & 14.828 & 0.855 & 0.642 \\
\hline TOB & 56.157 & 1 & 56.157 & 3.239 & 0.075 \\
\hline SEX & 34.531 & 4 & 8.633 & 0.498 & 0.737 \\
\hline AGE* SEX & | 43.447 & 15 & 9.563 & 0.552 & 0.904 \\
\hline AGE*TOB & 13.412 & I & 13.412 & 0.774 & 0.381 \\
\hline Error & 1716.289 & 99 & 17.336 & & \\
\hline \multicolumn{6}{|c|}{ Age at First Lambing $(R 2=45.0)$} \\
\hline Location & 71.103 & 2 & 35.552 & 2.869 & 0.061 \\
\hline AGE & 490.39 & 20 & 24.519 & 1.979 & 0.015 \\
\hline TOB & 21.856 & I & 21.856 & 1.764 & 0.187 \\
\hline SEX & 21.611 & 4 & 5.403 & 0.436 & 0.782 \\
\hline AGE* SEX & 173.448 & 15 & 11.563 & 0.933 & 0.531 \\
\hline AGE*TOB & $|8.06|$ & I & $|8.06|$ & 1.457 & 0.23 \\
\hline Error & 1226.862 & 99 & 12.393 & & \\
\hline
\end{tabular}

\section{Discussion}

Evaluation of the reproductive traits of local sheep breeds is an important part of categorization of their productive and reproductive performance. These traits possess more environmental and less genetic control. ${ }^{14}$ Therefore, the importance of non-genetic factors affecting reproductive performance needs investigation. Prolificacy is a combination of ovulation rate and embryo survival, number of lambs or kids born per parturition. Lower twinning rates as compared to present study were reported by a number of workers in other Ethiopian breeds. Mukasa Mugrewa et al. ${ }^{15}$ reported litter size (1.14) for Horro sheep in western Ethiopia, which is lower than the current findings.
Sharif et al. ${ }^{16}$ reported twinning rate in Balochi and Bibrik flocks as 1.0 and 2.0, respectively. Tariq et al. ${ }^{17}$ reported overall twinning rate in Mengali as $4.30 \%$. Jahan $\mathrm{M}$ et al. ${ }^{13}$ reports were similar with these findings in relation to the overall twinning rate, LI and AFL. Begayt sheep breeds have low twinning potential as compared to other breeds of the world and this trait could be improved through selection, better management and nutritional practices. In fact the potential of Begait sheep breeds has not been exploited properly.

\section{Age at first lambing}

This trait can be recorded easily in a farmer's flock and at farm levels. There is a big variation among production systems and breeds 
for this trait (12-24months). It is usually late in animals living in harsh environments. Age at first lambing for Balochi ewes (472.7days) was recorded by Jahan $\mathrm{M}$ et al. ${ }^{13}$ which is in agreement with the present study in Begayt ewes (490.4days) and 12month of AFL was reported by Getachew et al., ${ }^{18}$ in Ethiopian cross bred ewes which is lower than the present results. Average age at first lambing/kidding was reported between 10 to 13 months Belete $\mathrm{S}^{10}$ and Solomon et al. ${ }^{19}$ which is not in accordance with the results obtained in this study. On the other hand, reports from the southern part of Ethiopia shows an age at first lambing of 12.4 months Deribe $\mathrm{GT}^{20}$ which is shorter than the results obtained in the present study and the same author reported a lambing interval of 9.19 months which is similar with our study. Age at first service is a manage mental trait and can be minimized by improving nutritional and other management practices. Lower age at first lambing as compared to present study was reported by Berhanu $\mathrm{B}^{21}$ as $404 \pm 65.4$ days. The differences might be due to breed differences geographical location, and management practices.

\section{Lambing interval}

This refers to the number of days between successive parturitions. The mean LI for Begayt ewes in different farms were recorded $(256.60 \pm 0.3)$. The lambing interval as obtained in present study was in line with findings of Jahan $\mathrm{M}$ et al., ${ }^{13}$ Berhanu $\mathrm{B}$ et al., ${ }^{21}$ who reported lambing interval as $262 \pm 53$.4days in sheep. Lambing interval depends upon service period and gestation period. Former trait can be controlled but the latter is a biological trait and controlled genetically. Lambing interval was not affected $(p>0.05)$ by location, year of lambing, season of lambing and parity of ewe. As the reports of workers show Lambing interval of Begayt ewes (296.6days) was higher than the lambing interval of other local Ethiopian ewes (247.6 days) The lambing intervals reported in the present study was longer than that of 7.87-8.04months reported by Mukasa-ME et al., ${ }^{22}$ in Ethiopian highlands and that of ${ }^{10}$ in Gomma district but the LI obtained in the present study was shorter than reports, ${ }^{11} 12.1$ months Therefore, the variation in LI might be attributed to differences in feeding and breeding management practices. These differences might be due to variation in flock management and feeding regime.

\section{Conclusion}

The reproductive performance of native sheep mainly Begayt breeds is poor. ${ }^{23}$ Since, small ruminants, particularly sheep are one of the expected livestock species that serve as income sources of farmers, emphasis should be given by researchers and decision makers to balance the indigenous sheep genetics and improve their reproductive performance. Reproductive performance of Begait sheep was influenced by most of the non-genetic factors. Reproductive performance could be improved through genetics and environment. Therefore, genetic aspects should be explored to reveal the control of genes on the reproductive traits and emphasis should be laid on the improvement in management, nutrition and breeding practices. This study looks into all aspects of sheep production in the area and gave recommendations for the improvement of the entire system.

\section{Acknowledgements}

None.

\section{Conflict of interest}

Author declares that there is no conflict of interest.

\section{References}

1. Adane Yirpa, Girma Abebe. Economic significance of sheep and goats In: Alemu, editor. Sheep and Goat Production Handbook for Ethiopia. Addis Ababa, Ethiopia: ESGPIP (Ethiopia Sheep and Goats Productivity Improvement Program); 2008:2-24 p.

2. Biffa D, Jobre Y, Chakka H. Ovine helminthosis, a major health constraint to productivity of sheep in Ethiopia. Anim health Res Rev. 2006;7(1-2):107-118.

3. Mourad R, Aynalem H, Zeleke M, et al. Review of the reproductive performances of sheep breeds in Ethiopia. ICARDA. 2008. 23p.

4. http://www.esgpip.org/handbook/Handbook_PDF/Chapter\%205\%20 Reproduction\%20in\%20Sheep\%20and\%20Goats.pdf

5. Gizaw S, Van Arendonk JA, Komen H, et al. Population structure, genetic variation and morphological diversity in indigenous sheep of Ethiopia. Anim Genet. 2007;38(6):621-628.

6. Abebe Y. Assessment of small ruminant production systems and onfarm evaluation of urea treated wheat straw and concentrate feeding on sheep body weight change in Burie Woreda, West Gojjam. Ethiopia: MSc Thesis, Haramaya University. 2010. p. 1-208.

7. Getachew T, Haile A, Tibbo M, et al. Herd management and breeding practices of sheep owners in a mixed crop-livestock and a pastoral system of Ethiopia. African Journal of Agricultural Research. 2010;5(8):685-691.

8. Agricultural Sample Survey, Statistical Bulletin NO 578, Volume II, Addis Ababa, CSA. 2015.

9. FAO (Food and Agricultural Organization of the United Nations) FAOSTAT data. 2004

10. Belete S. Production and marketing systems of small ruminants in Goma district of Jimma zone, western Ethiopia. CGIAR. 2009.

11. Samuel M. Characterization of livestock production system: of East Showa, Ethiopia. Ethiopia: MS Thesis. Alemaya University, 2005.

12. Tolera A. Production situation and someproductivity and physical characters of traditionally managed sheep and goats in Kochore Woreda, southern Ethiopia. Journal of Applied Animal Research. 1998;13(1-2):49-59.

13. Jahan M, Tariq MM, Kakar MA, et al. Reproductive performance of Balochi sheep in different ecological zones of Balochistan, Pakistan. Pak Vet J. 2013;33(1):37-40.

14. Tailor SP, Gupta L, Nagda RK. Productive and reproductive performance of Sonadi sheep in their native tract. Indian Journal of Small Ruminants. 2006;13(1):51-54.

15. Mukasa ME, Anindo D, Sovani S, et al. Reproductive performance and productivity of Menz and Horro sheep lambing in the wet and dry seasons in the highlands of Ethiopia. Small Ruminant Research. 2002;45(3):261-271.

16. Sharif MK, Tariq MM, Waheed A, et al. Evaluation of economic traits of Balochi and Bibrik (Beverigh) sheep breeds of Balochistan, Pakistan. Iğdır Üni Fen Bilimleri Enst Der. 2011;1(2):133-139.

17. Tariq MM, Bajwa MA, Abbas F, et al. Some morphological, fertility and growth traits for Mengali sheep of Balochistan Pakistan. I $\breve{g} d 1 r$ Univ J Inst Sci Tech. 2011;1(1):63-68.

18. Getachew T, Gizaw S, Lemma S, et al. Effect of Crossbreeding Indigenous Sheep with Awassi and Corriedale Sires on Reproductive Performance under Smallholder Production System in Ethiopia. Agric conspec sci. 2013;78(3):187-191. 
19. Solomon G, Solomon A, Yohannes G. Factors affecting pre-weaning survival of Horro lambs at Bako Research Center. In: Proceedings of the 3rd Annual Conference of Ethiopian Society of Animal Production (ESAP). Addis Ababa, Ethiopia; 1995. p. 140-145.

20. Deribe GT. On-farm performance evaluation of indigenous sheep and goats in Alaba, Southern Ethiopia. MSc Thesis, 2009. p. 1-176.

21. Berhanu B, Aynalem H. Reproductive performance of traditionally managed sheep in the south western part of Ethiopia. Livestock Research for Rural Development. 2009:21(9).
22. Mukasa ME, Lahlou-Kassi A. Reproductive performance and productivity of Menz sheep in the Ethiopian highlands. Small Ruminant Research. 1995;17(2):167-177.

23. Khan MD, Ahmad N, Samad HA, et al. Reproductive efficiency of Rambouillet X Kaghani cross bred sheep. International Journal of Agriculture \&Biology. 2000;2(4):278-281. 